\title{
MLPA analysis of 32 foetuses with a congenital heart defect and 1 foetus with renal defects - pilot study. The significant frequency rate of presented pathological CNV
}

\author{
Andrea Stefekovaa, , Pavlina Capkovaa, , Zuzana Capkova a,b, Vaclava Curtisovaa, Josef Srovnal c,d, Enkhjargalan Mrackaa,b, \\ Eva Klaskovab, ${ }^{\mathrm{b},}$, Martin Prochazka ${ }^{\mathrm{a}, \mathrm{b}}$
}

\begin{abstract}
Aims. The aim of this retrospective study was to determine the detection rate of the pathogenic copy number variants $(C N V s)$ in a cohort of 33 foetuses -32 with CHD (congenital heart defects) and 1 with kidney defect, after exclusion of common aneuploidies (trisomy 13, 18, 21, and monosomy X) by karyotyping, Multiplex ligation - dependent probe amplification (MLPA) and chromosomal microarray analysis (CMA). We also assess the effectivity of MLPA as a method of the first tier for quick and inexpensive detection of mutations, causing congenital malformations in foetuses.

Methods. MLPA with probe mixes P070, P036 - Telomere 3 and 5, P245 - microdeletions, P250 - DiGeorge syndrome, and P311 - CHD (Congenital heart defects) was performed in 33 samples of amniotic fluid and chorionic villi. CMA was performed in 10 relevant cases.

Results. Pathogenic CNVs were found in 5 samples: microdeletions in region $22 q 11.2(\approx 2 \mathrm{Mb})$ in two foetuses, one distal microdeletion of the 22q11.2 region containing genes LZTR1, CRKL, AIFM3 and SNAP29 $(\approx 416 \mathrm{~kb})$ in the foetus with bilateral renal agenesis, 8p23.1 (3.8 Mb) microdeletion syndrome and microdeletion in area 9q34.3 (1.7 Mb, Kleefstra syndrome). MLPA as an initial screening method revealed unambiguously pathogenic CNVs in $15.2 \%$ of samples.

Conclusion. Our study suggests that MLPA and CMA are a reliable and high-resolution technology and should be used as the first-tier test for prenatal diagnosis of congenital heart disease. Determination of the cause of the abnormality is crucial for genetic counselling and further management of the pregnancy.
\end{abstract}

Key words: congenital heart defect, bilateral renal agenesis, clinical variability, copy number variants

Received: November 16, 2020; Revised: December 10, 2020; Accepted: March 17, 2021; Available online: March 31, 2021

https://doi.org/10.5507/bp.2021.019

(c) 2022 The Authors; https://creativecommons.org/licenses/by/4.0/

${ }^{a}$ Department of Medical Genetics, University Hospital Olomouc, Czech Republic

${ }^{b}$ Faculty of Medicine and Dentistry, Palacky University Olomouc, Olomouc, Czech Republic

'Institute of Molecular and Translational Medicine, Faculty of Medicine and Dentistry, Palacky University Olomouc, Czech Republic

${ }^{d}$ Department of Pediatrics, University Hospital Olomouc, Czech Republic

Corresponding author: Pavlina Capkova, e-mail:pavlina.capkova@fnol.cz

\section{INTRODUCTION}

Congenital heart defects (CHD) are the most common group of structural abnormalities at birth, with an estimated prevalence of $1-5 \%$ of live births, constituting one of the main causes of infant morbidity and mortality $^{1,2}$. The early detection of foetus malformations in prenatal diagnosis is crucial for the assessment of the further possible comorbidities. As not all comorbidities are detectable by ultrasound, it is recommended that in all pregnancies with $\mathrm{CHD}, \mathrm{CNV}$ s should be excluded, using appropriate methods including cytogenetic techniques, FISH, and DNA mutation analysis (MLPA, array CGH), targeting especially areas linked to known syndromes ${ }^{3}$.

CHDs are either isolated or syndromic. In syndromic cases extra-cardiac abnormalities may be present in the foetus. Extra-cardiac malformations have a substantial role in cardiac diseases and their detection in patients with CHD is very important. Proper diagnosis and early treatment of these abnormalities have a great impact on a patient's life quality. Extra-cardiac malformations, such as intra-abdominal organ defects associated with genetic syndromes, are observed from $7 \%$ to $50 \%$ in cases with congenital heart diseases. Extra-cardiac abnormalities were observed in $10 \%\left(\right.$ ref. $^{4}$ ) and $31 \%$ (ref. ${ }^{5}$ ) cases, performed in Czech Republic mainly in two retrospective studies. As a result, the risk of morbidity and mortality of these patients is increased ${ }^{6-8}$. Abnormalities of the central nervous system, gastrointestinal system, kidneys, urogenital system, as well as of the abdominal wall are among frequent extra-cardiac malformations ${ }^{9}$. Congenital renal agenesis is the complete absence of renal tissue. This can be unilateral (unilateral renal agenesis, URA) and bilateral (bilateral renal agenesis, BRA). Bilateral renal agenesis is incompatible with life ${ }^{10}$.

Significance of CNV in patients with a congenital heart defect and extra-cardiac malformations

Approximately $20-25 \%$ of cardiac malformations are associated with a genetic cause ${ }^{11}$. Chromosomal aberrations are a frequent cause of CHDs and in these patients extra-cardiac malformations are often seen ${ }^{12,13}$. The most 
common are trisomy $13,18,21$, or monosomy X. CNV are also relatively common causes of CHD (e.g. microdeletion 22q11.2, 7q11.23, 1p36.33). Studies of patients with CHD indicate that CNVs are a major genetic cause of cardiovascular disease, occurring in $3-25 \%$ of patients with extra-cardiac abnormalities and in $3-10 \%$ with isolated heart defects ${ }^{14}$. The pathogenic significance of a particular CNV is highly dependent on the position of its breakpoints, the genomic content of deleted or duplicated segments, and the genomic area in which the CNV is situated. While copy number variations are now regarded as a major cause of genetic disease, it is important to underline that not all CNVs are pathogenic.

\section{MATERIALS AND METHODS}

\section{CHD patients}

We tested 32 samples of amniotic fluid from pregnancies with foetuses with heart defects and one sample of a foetus with a congenital renal defect detected by ultrasound. Ultrasound examination was performed in the
Institute of foetal medicine, University Hospital Olomouc and patients were counselled by a clinical geneticist of the Department of Medical Genetics, there.

18 foetuses were male and 15 were female. The age of patients was 19 - 39 years and the gestation age ranged from 19-24 weeks.

Samples were isolated by QIAamp DNA Mini Kit (Qiagen, CA, USA). DNA concentration and purity were evaluated using the NanoDrop2000 spectrophotometer (Thermo Scientific, Waltham, USA). Signed informed consent was obtained from patients.

\section{Cytogenetic analysis}

All samples were processed and karyotyped according to standard laboratory protocols. Samples with common trisomies were excluded from the study group. All analyzed samples had normal karyotypes.

Multiplex ligation-dependent probe amplification (MLPA)

Probe mixes P070, P036 - Telomere 3 and 5, P245 microdeletions, P250 - DiGeorge syndrome, and P311 - CHD (MRC-Holland, Amsterdam, Netherlands) were

Table 1. Distribution of the types of heart defects in the cohort.

\begin{tabular}{|c|c|c|}
\hline Type of heart defect & & $\mathrm{n}$ \\
\hline \multirow[t]{3}{*}{ Septal defects } & VSD & 15 \\
\hline & ASD & 1 \\
\hline & AVSD & 5 \\
\hline Ventricular defects & hypoplastic left ventricle & 2 \\
\hline \multirow[t]{7}{*}{ Valvular defects } & mitral stenosis & 1 \\
\hline & mitral dysplasia & 1 \\
\hline & tricuspid stenosis & 1 \\
\hline & tricuspid atresia & 3 \\
\hline & tricuspid insufficiency & 2 \\
\hline & pulmonary atresia & 1 \\
\hline & pulmonary stenosis & 1 \\
\hline \multirow[t]{3}{*}{ Defects of pulmonary arteria } & hypoplasia & 3 \\
\hline & atresia & 2 \\
\hline & stenosis & 2 \\
\hline \multirow[t]{6}{*}{ Defects of the aorta and aortic arch } & aortic atresia & 2 \\
\hline & coarctation of the aorta & 3 \\
\hline & aorta connection to VSD & 1 \\
\hline & right side aortic arch & 2 \\
\hline & hypoplasia of aortic arch & 1 \\
\hline & coarctation of aortic arch & 1 \\
\hline \multirow[t]{3}{*}{ Pathology of great arteries } & transposition & 4 \\
\hline & malposition & 2 \\
\hline & unspecified & 2 \\
\hline Tetralogy of Fallot & & 4 \\
\hline Double-outlet right ventricle (DORV) & & 3 \\
\hline Hypoplastic right heart & & 3 \\
\hline
\end{tabular}

$n$, number of presented defects 
used for the DNA analysis according to the manufacturer's protocol. A mix of $1 \mu \mathrm{L}$ PCR product, $13.46 \mu \mathrm{L}$ Hi-Di formamide and $0.54 \mu \mathrm{L}$ LIZ-GS500 Size Standard (Life Technologies) was analysed by capillary electrophoresis in an ABI 3130 Genetic Analyser (Applied Biosystems, Foster City, USA). MLPA data were collected using GeneMapper software (Applied Biosystems, Foster City, USA), and subsequently analysed with three control samples by the Coffalyser software.

All pathogenic CNVs were verified either with another probe mix or with an independent method (FISH, aCGH). FISH - probes DG/VCFS critical region at 22q11.2 and 8p23.1 (D22S75, Cytocell, UK, RP11-235I5, BlueGnome) was performed according to the manufacturer 's protocol. CMA (Affymetrix, Santa Clara, USA) was performed in collaboration with the Institute of Molecular and Translation Medicine in Olomouc, Czech Republic.

\section{RESULTS}

This retrospective study included 32 foetuses with congenital heart disease and 1 foetus with bilateral renal agenesis. In our small cohort pathogenic CNVs were detected by MLPA analysis in 5 cases (15.2\%) (Table 2). The spectrum of heart malformations was wide, ranging from simple lesions such as septal defects to complex defects, e.g., tetralogy of Fallot or the transposition of great arteries. The most frequently encountered abnormalities were ventricular septal defect, atrioventricular septal defect, and abnormal position of great arteries (Table 1).

\section{2q11.2 deletion syndrome}

22 q11.2 deletion was the most prevalent condition, found in three male foetuses. This well-known microde- letion containing CLTCL1, HIRA25, CDC45, CLDN5, GP1BB, TBX1, TXNRD2, DGCR8, ZNF74, KLHL22, MED15, SNAP29, and LZTR1 genes was revealed in patient $1 a$, who had a tetralogy of Fallot. We do not have any additional information about this patient.

Patient $2 a$ - male foetus, inherited the microdeletion from his mother. The microdeletion contained the CLTCL1, HIRA25, CDC45, CLDN5, GP1BB, TBX1, TXNRD2, DGCR8, ZNF74, KLHL22, MED15, SNAP29, and LZTR1 genes and its size was estimated as $2 \mathrm{Mb}$. Ultrasound examination of the foetus bilateral talipes equinovarus; ventricular septal defect and megavesica were found at autopsy. The mother presented with thrombocytopenia, hypothyroidism, amblyacousia, and psychiatric disease; as a child she had an operation for cleft palate and patent ductus arteriosus. These features are typical of DiGeorge syndrome which was diagnosed in the mother and the foetus. According to the MLPA result, the deleted region was similar in patients $1 a$ and $2 a$.

In the third foetus ( $3 a$ ) with the loss at 22q11.2, CHD was suspected as a cause of IUD, however bilateral renal agenesis without cardiac abnormality was found at autopsy. Using MLPA we found deletion of two genes - SNAP29 and LZTR 1 in the foetus. The size of the microdeletion was determined by CMA as $416 \mathrm{~kb}$, and the method revealed a deletion of two additional genes - CRKL and AIFM3 in this location.

\section{8p23.1 deletion syndrome}

A complete atrioventricular septal defect, common ventricles and atrioventricular valve, aortic hypoplasia, transposition of great arteries, pulmonary stenosis, and hyperechogenic fetal bowel were revealed in female foetus $4 a$ in a primigravida woman, aged 20 at 21 weeks of pregnancy. Ultrasonographic examination at the $1 \mathrm{st}$

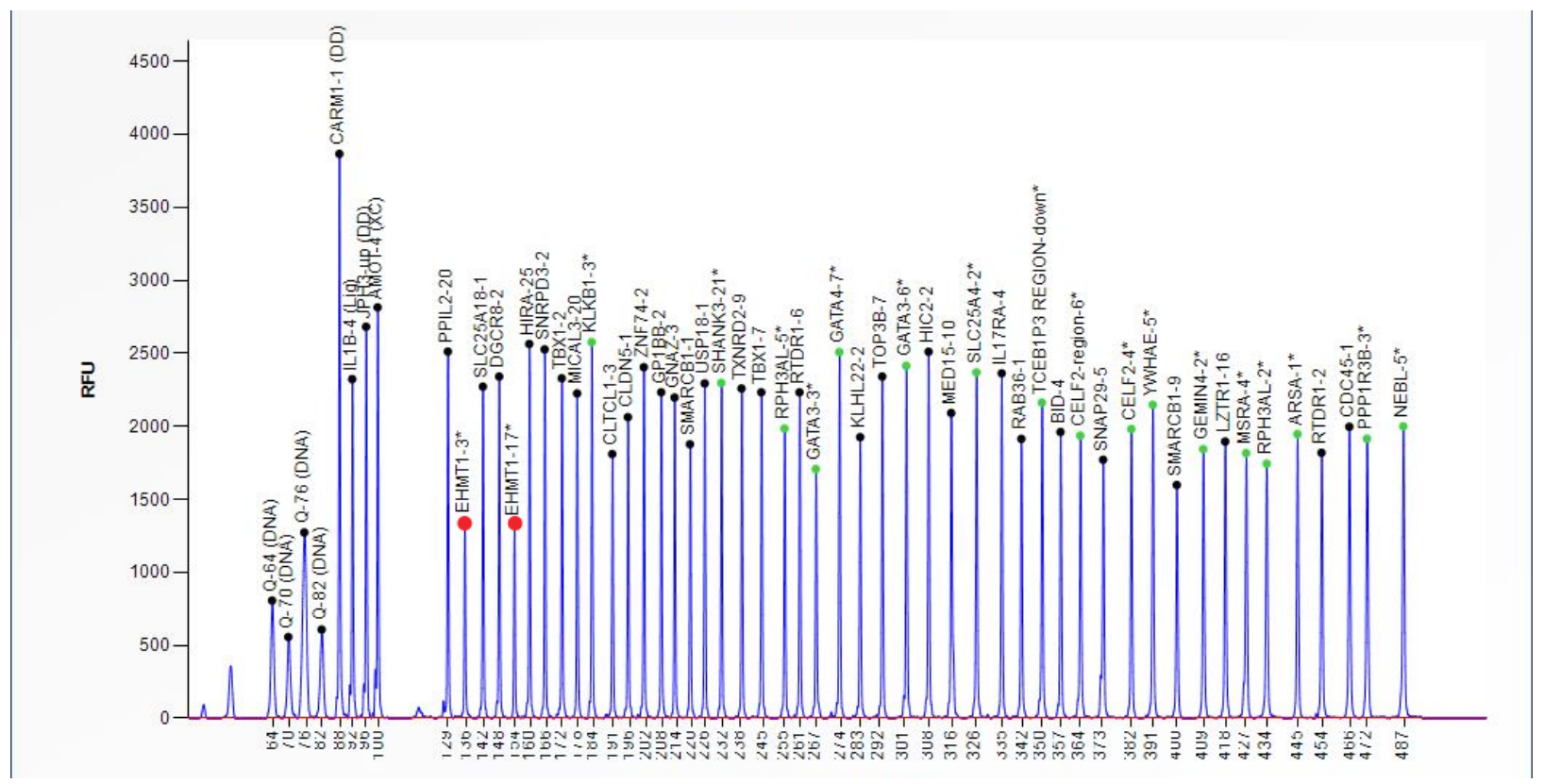

Fig. 1. The result from sample $3 a$ analysed by Coffalyser software. Bigger red round points show a peak pattern in the deleted EHMT1 region (probe mix P250 DiGeorge syndrome). 


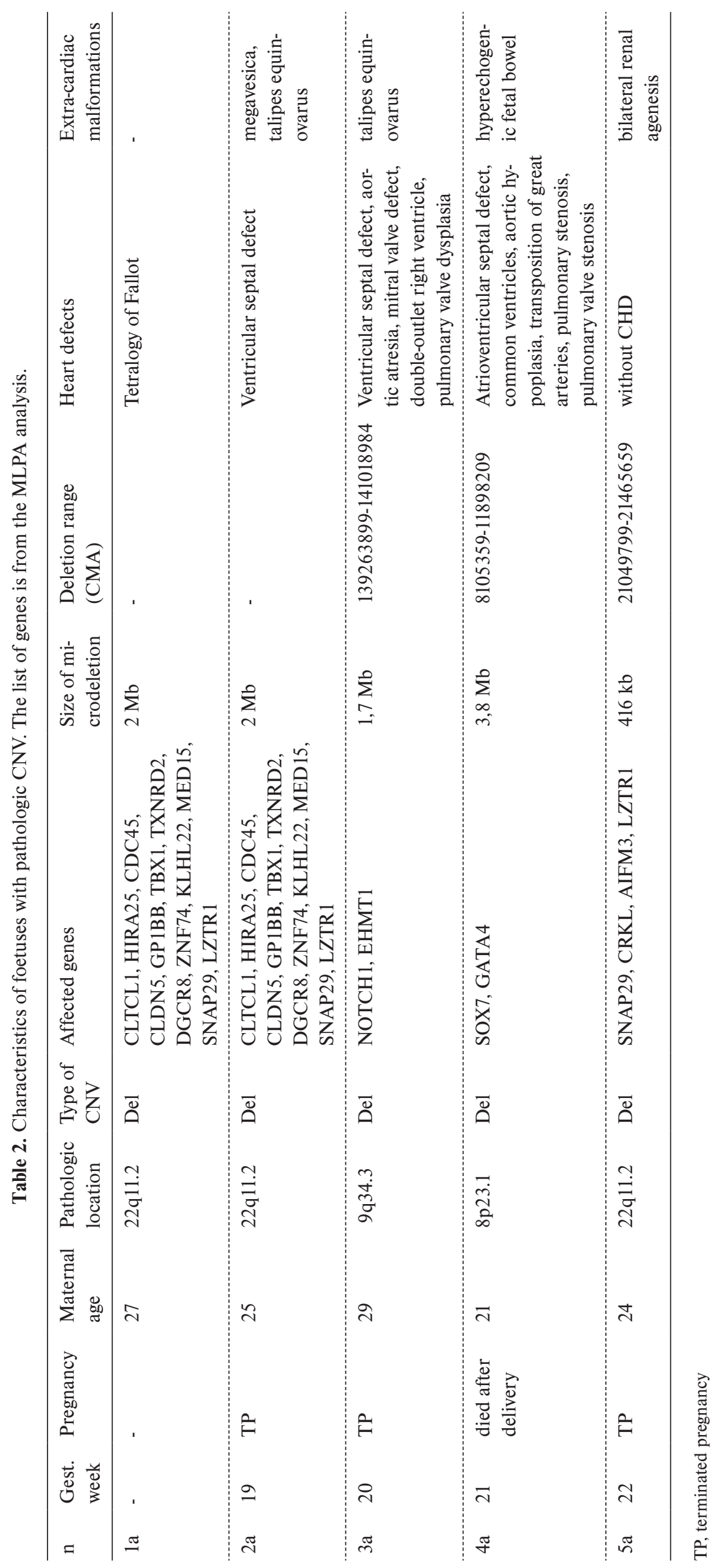


trimester was normal and first trimester combined screening was negative. Family history was negative regarding CHD. The pathogenic microdeletion of the $8 \mathrm{p} 23.1$ region was revealed by MLPA analysis in the foetus. The microdeletion was verified by whole genome SNP-microarray and its size was determined as 3.8 Mb [8p23.1 (810535911898209)x1]. The deleted region contained genes CLDN23, MFHAS1, ERI1, PPP1R3B, TNKS, MSRA, PRSS55, RP1L1, SOX7, PINX1, XKR6, MTMR9, BLK, GATA4, NEIL2, FDFT1, and CTSB. The patient decided to continue the pregnancy. She delivered at term a baby small for gestational age (weight $2470 \mathrm{~g}$ ), Apgar score was 8-9-9. Hypotonia, acrocyanosis, and neck webbing were observed after delivery. The baby died at one week of age due to cardiac insufficiency.

\section{9q34.3 deletion}

In a female foetus $5 a$ ventricular septal defect, aortic atresia, mitral valve defect, double-outlet right ventricle, and left sided talipes equinovarus were detected during US examination. Nuchal translucency at the first-trimester screening was $2.6 \mathrm{~mm}$. The loss of EHMT1 was discovered using MLPA analysis with probe mix P250 DiGeorge syndrome (Fig. 1) and was confirmed by probe mix Telomere 3 and 5. The size of the microdeletion was determined by the whole genome SNP-microarray. The result of the CMA analysis was 9q34.3 (139263899-141018984)x1, the size of the deletion was $1,7 \mathrm{Mb}$ and contained 98 RefSeq genes, some of them were CARD9, NOTCH1, TRAF2, COBRA1, NELF, ZMYND19, ARRDC1, EHMT1, CACNA1B. This finding is consistent with Kleefstra syndrome. The pregnancy was terminated.

\section{DISCUSSION}

\section{Congenital heart malformations}

Methods such as FISH, MLPA, and chromosome microarray analysis are suitable for detecting chromosomal deletions. A common deletion size of approximately 3 $\mathrm{Mb}$ leads to the deletion of about 45 genes at 22q11.2 and results from recombination at rearrangement hotspots ${ }^{15}$. There are low copy repeats (LCR) in the common dele- tion region, marked $\mathrm{A}$ to $\mathrm{D}$, and they are vulnerable to rearrangements. The deletions are caused by non-allelic homologous recombination that creates deletions of variable size, where $3 \mathrm{Mb}, 2 \mathrm{Mb}$, and $1.5 \mathrm{Mb}$ are the most common (Fig. 2.) (ref. ${ }^{23,31}$ ). The sizes correspond to deletions flanked by LCR-A to D, LCR-A to C and LCR-A to $\mathrm{B}$, respectively ${ }^{16}$.

It is well-known that $22 \mathrm{q} 11.2$ is the second main cause of CHD (ref. ${ }^{17}$ ) after Down syndrome ${ }^{12}$, and this syndrome was the most frequent disorder in our cohort $(9.1 \%)$. This is consistent with the findings of other studies $\left[7.3 \%\right.$ (ref. $^{13}$ ), $6.4 \%\left(\right.$ ref. $^{18}$ ) and $8.5 \%\left(\right.$ ref. $\left.^{19}\right)$ ]. The most common extra-cardiac malformations in this syndrome affect the central nervous system, kidneys, urinary tract, genital system, gastrointestinal, and respiratory system ${ }^{9,20}$.

There is a considerable variability in clinical presentations associated with deletions in this region ${ }^{20-22}$. Apparently, the heterozygotic loss of particular genes has a different impact. This phenomenon is demonstrated in our case with congenital kidney malformations (CMK) without CHD. Prenatally detected heart defects are frequently associated with malformations of other organs. In one study the authors found that CDC45 is a causative gene in craniosynostosis ${ }^{23}$, deletion of genes HIRA, DGCR8, and SNAP29 suggests a possible etiologic association with anomalous pulmonary venous connection (APVC) $\left(\right.$ ref. $\left.^{24}\right)$. Haploinsufficiency of TBX1 is considered as the major contributor to the 22q11.2DS phenotype, as it has been associated with CHD and palate anomalies ${ }^{25-27}$.

Congenital kidney and urinary tract anomalies are present in approximately $30 \%$ of the patients with the DiGeorge syndrome ${ }^{28-30}$. We found a loss of SNAP29 and LZTR1 genes by MLPA, and CRKL and AIFM3 genes by aCGH in the region $22 \mathrm{q} 11.2$ in the foetus, where the autopsy revealed only bilateral renal agenesis. Very similar $410 \mathrm{~kb}$ deletion in the same area was found in the foetus P6 with bilateral renal agenesis (Fig. 2.) (ref. ${ }^{31}$ ). The authors carried out functional studies using zebrafish and mice. Inactivation of CRKL in the mouse model induced developmental defects similar to those observed in patients with congenital urinary anomalies. It has been assumed that a recurrent $370 \mathrm{~kb}$ deletion in $22 \mathrm{q} 11.2$ locus is a cause

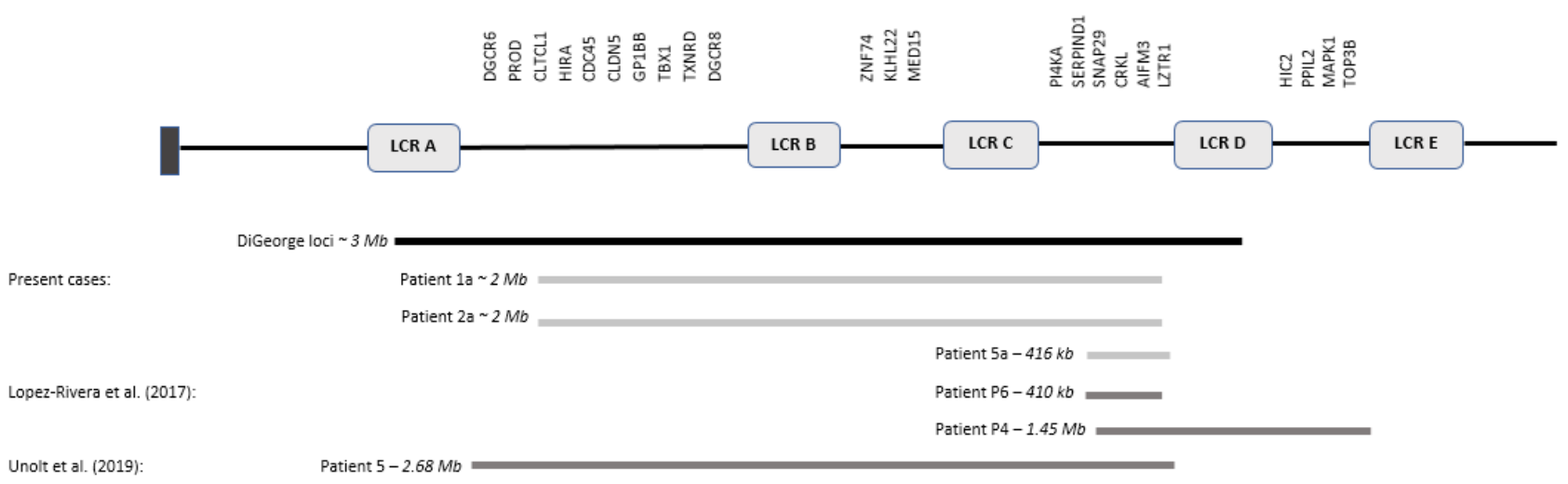

Fig. 2. The most common deletions in LCR region in DiGeorge syndrome, comparing our findings with literature. 
of renal defects in DiGeorge syndrome and in sporadic congenital kidney and urinary tract anomalies. Of the 9 genes at this locus, SNAP29, CRKL, and AIFM3 appear to be crucial to the phenotype, with haploinsufficiency of CRKL emerging as the main genetic factor ${ }^{31}$.

Faivre et al. ${ }^{32}$ reported the first case of an 8 p23.1 deletion ascertained prenatally. A second-trimester ultrasound examination revealed a posterior left sided diaphragmatic hernia, with intra-thoracic stomach and spleen without a heart defect. Cytogenetic analysis showed a terminal deletion of the short arm of chromosome $8 \mathrm{p} 23.1$. The region 8 p23.1 contains genes that are involved in the development of heart such as SOX7 (ref. ${ }^{33}$ ) and GATA4 (ref. ${ }^{34}$ ). This deletion was also found in a study where $94 \%$ of tested patients had a cardiac disease and $22 \%$ of patients had a congenital diaphragmatic hernia ${ }^{35}$. Recently studies in mice showed that interstitial deletions of 8 p23.1 associated with congenital heart disease and frequently include deletion of the GATA4 gene. The cardiac malformations seen in these mice included septal defects, right ventricular hypoplasia, endocardial cushion defects and cardiomyopathy ${ }^{36}$. Guimiot et al. ${ }^{37}$ described maternally inherited 5.6 Mb deletion in the foetus with an AV canal, the most common CHD encountered in interstitial 8p23.1 deletion $^{35,38}$. A $5.25 \mathrm{Mb}$ deletion in $8 \mathrm{p} 23.1$ was found in a foetus with atrio-ventricular septal defect ${ }^{39}$.

Kleefstra syndrome (KS) is caused by a mutation in EHMT1 gene described by Kleefstra et al. ${ }^{40,41}$. The syndrome is defined by intellectual disability, childhood hypotonia and distinct facial features with a large spectrum of additional clinical symptoms ${ }^{42,43}$. In patients with the disorder, heart defects, recurrent infections, and various anomalies in brain anatomy are frequently observed ${ }^{41}$. Guterman et al. ${ }^{44}$ reported a foetus with increased nuchal translucency $(3.1 \mathrm{~mm})$, coarctation of the aorta and short corpus callosum. aCGH was performed following a detection of a cardiac defect, and revealed a $870 \mathrm{~kb}$ deletion at $9 \mathrm{q} 34.3$ which included EHMT1 gene. However, previously reported cases were associated with other structural chromosomal abnormalities in addition to the deletion ${ }^{45-47}$. The DNA analysis was considered depending on ultrasound assessment result in prenatal cases ${ }^{45-50}$ or visible clinical characteristics in postnatal cases ${ }^{51-54}$.

\section{Incidence of CNVs in the foetuses with CHD}

Van den Veyver et al. (ref. ${ }^{55}$ ) analysed the potential utility of CNV analysis in cases of advanced maternal age or abnormal ultrasound findings. They found pathogenic CNVs in 5\% of 300 cases and gained new important information by chromosome microarray in $2.3 \%$.

Studies published thus far estimate that CNVs contribute to disease burden in approximately $3-25 \%$ of patients with CHDs with extra - cardiac anomalies (ECAs) and $3-10 \%$ of patients with isolated CHDs, indicating that $\mathrm{CNV}$ analysis can provide valuable diagnostic information in this patient population ${ }^{14}$. Notably, many of these studies performed 22q11.2 FISH before CNV analysis and excluded patients with positive results suggesting that the actual yield of chromosome microarray testing in the CHD population is even higher.
To date, it has been shown that approximately $40 \%$ of familial CHD, $20 \%$ of sporadic CHD, and $50 \%$ of $\mathrm{CHD}$ with extra - cardiac congenital anomalies have an identifiable genetic etiology ${ }^{56}$. A determination of precise etiology diagnosis has important implication for genetic counselling and an initiation of right subsequent treatment. The use of appropriate genetic methods is important for an early detection of syndromic causes.

These studies indicate that pathogenic CNVs can be detected in foetuses both with isolated CHDs and CHD with ECAs. Therefore, many laboratories use CMA as the first-tier test for detection of $\mathrm{CNV}$ in foetuses with $\mathrm{CHD}$. However, detection of VOUS CNV can cause additional burden to the parents. In these cases, MLPA might be used as the targeted screening for clinically relevant $\mathrm{CNV}$ detection.

Apart from probemix P250 - DiGeorge we also suggest using probe mix P311 - CHD which covers relevant genes involved in cardiogenesis.

\section{CONCLUSION}

Our retrospective study investigated the presence of copy number variants in foetuses with congenital heart and kidney defects. CNVs are an important part of the genetic diversity evolution and disease susceptibility. Detection and association with phenotypes are an important step for better understanding the aetiology of the disorder ${ }^{57}$. The use of specific molecular genetics methods allows us quickly and effectively detect genetic defects prenatally.

MLPA was used as a targeted test to determine CNVs. In our study of 33 cases of prenatally detected congenital malformations MLPA detected CNVs in 5 of them and proved its potential as a rapid diagnostic test in this context. MLPA testing with probe mix P250 and P311 is a reliable and fast tool for detection of the pathogenic CNVs in the foetuses with CHD. However, as we detected one further microdeletion with probe mixes P070 and P036, we recommend combining the probe mixes P250, P311, P245 and Telomere 3 and 5. Moreover, using these probe mixes proved to be useful in testing not only foetuses with CHD but also in foetuses with a different congenital defects and increased detection rate with a detection of a rare and very small (nested) microdeletion in the region $22 q 11.2$. For the relatively high frequency of microdeletion $22 q 11.2$ in prenatal testing and its segregation with a highly variable phenotype (wide spectrum of CHD, some with limited detectability by an ultrasound examination during pregnancy) it might be helpful to routinely screen for the microdeletion in the prenatal diagnosis.

Our study shows that using MLPA as the first line genetic test was highly effective in the detection of clinically significant chromosomal abnormalities in foetuses with congenital heart disease. MLPA is a low-cost technique convenient especially for detection of recurrent pathogenic CNVs in prenatal diagnosis of CHD. Comparing to CMA, MLPA was easier to perform, analyse and interpret in the diagnostic setting. 
We conclude that our approach of using the combination of the P250, P311, P245, P036, and P070 MLPA kits is a suitable initial screening tool in patients with heart malformations. However, as MLPA is a targeted test, rare CNVs could be missed. For this reason, it is appropriate to supplement MLPA with other techniques, such as microarray or NGS analysis.

Acknowledgement: Supported by MH CZ-DRO (FNO1,00098892), Internal Grant Agency of Palacky University in Olomouc: IGA_LF_2020_007.

Author contributions: AS: data collection, manuscript writing, responsible for performed experiments, analysed the data, prepared figures, and tables; ZC: performed MLPA analysis; PC: data interpretation, final approval; VC, EM, JS, EK, MP; genetic consultation, data interpretation; EM, EK, MP: ultrasonographic assessment; MP: final approval.

Conflict of interest statement: The authors state that there are no conflicts of interest regarding the publication of this article.

\section{REFERENCES}

1. Hoffman Jl, Kaplan S. The incidence of congenital heart disease. J Am Coll Cardiol 2002;39(12):1890-900.

2. Wang E, Sun S, Qiao B, Duan W, Huang G, An Y, Xu S, Zheng Y, Su Z, Gu $X$, Jin $L$, Wang $H$. Identification of functional mutations in GATA4 in patients with congenital heart disease. PLoS One 2013;8(4):e62138.

3. Silva M, Leeuw N, Mann K, Schuring-Blom H, Morgan S, Giardino D, Rack K, Hastings R. European guidelines for constitutional cytogenomic analysis. Eur J Hum Genet 2019;27(1):1-16.

4. Pavlicek J, Piegzová A, Klásková E, Kaprálová S, Palatová A, Spacek R, Gruzska T. Development, effectiveness, and current possibilities in prenatal detection of congenital heart defects. Cor Vasa 2020;62:2128.

5. Marek J, Tomek V, Skovránek J, Povysilová V, Samánek M. Prenatal ultrasound screening of congenital heart disease in an unselected national population: a 21-year experience. Heart 2011;97(2):124-30.

6. Grech V, Gatt M. Syndromes and malformations associated with congenital heart disease in a population-based study. Int J Cardiol 1999;68(2):151-6.

7. Marino B, Digilio MC. Congenital heart disease and genetic syndromes: specific correlation between cardiac phenotype and genotype. Cardiovasc Pathol 2000;9(6):303-15.

8. Gonzalez JH, Shirali GS, Atz AM, Taylor SN, Forbus GA, Zyblewski SC Hlavacek AM. Universal screening for extracardiac abnormalities in neonates with congenital heart disease. Pediatr Cardiol 2009;30(3):269-73.

9. Tennstedt C, Chaoui R, Körner H, Dietel M. Spectrum of congenital heart defects and extracardiac malformations associated with chromosomal abnormalities: result of a seven year necropsy study. Heart 1999;82(1):34-39.

10. Sanna-Cherchi S, Ravani P, Corbani V, Parodi S, Haupt R, Piaggio G, Innocenti ML, Somenzi D, Trivelli A, Caridi G, Izzi C, Scolari F, Mattioli G, Allegri L, Ghiggeri GM. Renal outcome in patients with congenital anomalies of the kidney and urinary tract. Kidney Int 2009;76(5):52833.

11. Blue GM, Kirk EP, Sholler GF, Harvey RP, Winlaw DS. Congenital heart disease: current knowledge about causes and inheritance. Med J of Australia 2012;197(3):155-9.

12. Pierpont ME, Basson CT, Benson DW Jr, Gelb BD, Giglia TM, Goldmuntz E, McGee G, Sable CA, Srivastava D, Webb CL. Genetic basis for congenital heart defects: current knowledge: a scientific statement from the American Heart Association Congenita Cardiac Defects Committee, Council on Cardiovascular Disease in the Young: endorsed by the American Academy of Pediatrics. Circul 2007;115(23):3015-38.
13. Mademont-Soler I, Morales C, Soler A, Clusellas N, Margarit E, Estefanía Martínez-Barrios E, Martínez JM, Sánchez A. MLPA: A prenatal diagnostic tool for the study of congenital heart defects? Gene 2012;500(1):151-54.

14. Lander J, Ware SM. Copy number variation in congenital heart defects. Curr Genet Med Rep 2014;2:168-78.

15. Edelmann L, Pandita RK, Morrow BE. Low-copy repeats mediate the common 3-Mb deletion in patients with velo-cardio-facial syndrome. Am J Hum Genet 1999;64(4):1076-86.

16. Bittel DC, Yu S, Newkirk H, Kibiryeva N, Holt A, Butler MG, et al. Refining the 22q11.2 deletion breakpoints in DiGeorge syndrome by aCGH. Cytog Gen Res 2009;124(2):113-20.

17. Ware SM, Jefferies JL. New genetic insights into congenital heart disease. J Clin Exp Cardiolog 2012;15(S8):pii:003.

18. Mademont-Soler I, Morales C, Soler A, Martınez-Crespo JM, Shen Y, Margarit E, Clusellas N, Obon M, Wu BL, Sanchez A. Prenatal diagnosis of chromosomal abnormalities in fetuses with abnormal cardiac ultrasound findings: evaluation of chromosomal microarray-based analysis. Ultrasound Obstet Gynecol 2013;41(4):375-82.

19. Monteiro RAC, de Freitas ML, Vianna GS, de Oliveira VT, Pietra RX, Ferreira LCA, Rocha PPO, da S. Gonçalves M, da C. César G, de S. Lima J, Medeiros PFV, Mazzeu JF, Jehee FS. Major Contribution of Genomic Copy Number Variation in Syndromic Congenital Heart Disease: The Use of MLPA as the First Genetic Test. Mol Syndromol 2017;8(5):227-35.

20. Song MS, Hu A, Dyhamenhali U, Chitayat D, Winsor EJT, Ryan G, Smallhorn J, Barrett J, S. Yoo J, Hornberger LK. Extracardiac lesions and chromosomal abnormalities associated with major fetal heart defects: comparison of intrauterine, postnatal and postmortem diagnoses. Ultras Obst Gyn 2009;33(5):552-59.

21. Noël AC, Pelluard F, Delezoide AL, Devisme $L$, Loeuillet $L$, Leroy $B$, Martin A, Bouvier R, Laquerriere A, Jeanne-Pasuier C, BessieresGrattagliano B, Mechler C, Alanio E, Leroy C, Gaillard D. Fetal phenotype associated with the $22 q 11$ deletion. Am J Med Genet A 2014;164A(11):2724-31.

22. Burnside RD. 22q11.21 Deletion syndromes: a review of proximal, central, and distal deletions and their associated features. Cyto Gen Res 2015;146(2):89-99.

23. Unolt M, Kammoun M, Nowakowska B, Graham GE, Crowley TB, Hestand MS, Demaerel W, Geremek M, Emanuel BS, Zackai EH, Vermeesch JR, McDonald-McGinn D. Pathogenic variants in CDC45 on the remaining allele in patients with a chromosome 22 q11.2 deletion result in a novel autosomal recessive condition. Genet Med 2020;22(2):326-35.

24. Cao R, Liu S, Liu C, Chen S, Li F, Sun K, Xu R. Duplication and Deletion of 22q11 Associated with Anomalous Pulmonary Venous Connection. Ped Cardiol 2018;39(3);585-90.

25. Lindsay EA, Vitelli F, Su H, Morishima M, Huynh T, Pramparo T, Jurecic V, Ogunrinu G, Sutherland HF, Scambler PJ, Bradley A, Baldini A. Tbx1 haploinsufficieny in the DiGeorge syndrome region causes aortic arch defects in mice. Nature 2001;410(6824):97-101.

26. Yagi H, Furutani $Y$, Hamada H, Sasaki T, Asakawa S, Minoshima S, Ichida F, Joo K, Kimura M, Imamura S, Kamatani N, Momma K, Takao A, Nakazawa M, Shimizu N, Matsuoka R. Role of TBX1 in human del22q11.2 syndrome. Lancet 2003;362(9393):1366-73.

27. Paylor R, Glaser B, Mupo A, Ataliotis P, Spencer C, Sobotka A, Sparks C, Choi CH, Oghalai J, Curran S, Murphy KC, Monks S, Williams N, O'Donovan MC, Owen MJ, Scambler PJ, Lindsay E. Tbx1 haploinsufficiency is linked to behavioral disorders in mice and humans: implications for 22q11 deletion syndrome. Proc Natl Acad Sci U S A 2006;103(20):7729-34.

28. Wilson DI, Burn J, Scambler P, Goodship L. DiGeorge syndrome: part of CATCH 22. J Med Genet 1993;30(10):852-6.

29. Kujat A, Schulz MD, Strenge S, Froster UG. Renal malformations in deletion 22q11.2 patients. Am J Med Genet A 2006;140(14):1601-2.

30. Kobrynski LJ, Sullivan KE. Velocardiofacial syndrome, DiGeorge syndrome: the chromosome 22q11.2 deletion syndromes. Lancet 2007;370(9596):1443-52.

31. Lopez-Rivera E, Liu YP, Verbitsky M, Anderson BR, Capone VP, Otto EA Yan Z, Mitrotti A, Martino J, Steers NJ, Fasel DA, Vukojevic K, Deng R, Racedo SE, Liu Q, Werth M, Westland R, Vivante A, Makar GS, Bodria M, Sampson MG, Gillies CE, Vega-Warner V, Maiorana M, Petrey DS, Honig B, Lozanovski VJ, Salomon R, Heidet L, Carpentier W, Gaillard D, Carrea A, Gesualdo L, Cusi D, Izzi C, Scolari F, van Wijk JA, Arapovic A, Saraga-Babic M, Saraga M, Kunac N, Samii A, McDonald-McGinn 
DM, Crowley TB, Zackai EH, Drozdz D, Miklaszewska M, Tkaczyk M, Sikora P, Szczepanska M, Mizerska-Wasiak M, Krzemien G, Szmigielska A, Zaniew M, Darlow JM, Puri P, Barton D, Casolari E, Furth SL, Warady BA, Gucev Z, Hakonarson H, Flogelova H, Tasic V, Latos-Bielenska A, Materna-Kiryluk A, Allegri L, Wong CS, Drummond IA, D'Agati V, Imamoto A, Barasch JM, Hildebrandt F, Kiryluk K, Lifton RP, Morrow BE, Jeanpierre C, Papaioannou VE, Ghiggeri GM, Gharav AG, Katsanis N, Sanna-Cherchi S. Genetic Drivers of Kidney Defects in the DiGeorge Syndrome. N Engl J Med 2017;376(8):742-54.

32. Faivre L, Morichon-Delvallez N, Viot G, Narcy F, Loison S, Mandelbrot L, Aubry MC, Raclin V, Edery P, Munnich A, Vekemans M. Prenatal diagnosis of an 8p23.1 deletion in a fetus with a diaphragmatic hernia and review of the literature. Prenat Diagn 1998;18(10):1055-60.

33. Long F, Wang X, Fang S, Xu Y, Sun K, Chen S, Xu R. A Potential Relationship among beta-defensins haplotype, SOX7 duplication and cardiac defects. PLoS ONE 2013;8(8):e72515.

34. Rajagopal SK, Qing M, Obler D, Jie S, Manichaikul A, Tomita-Mitchell A, Boardman K, Briggs C, Garg V, Srivastava D, Goldmuntz E, Broman KW, Woodrow Benson D, Smoot LB, William PT. Spectrum of heart disease associated with murine and human GATA4 mutation. J Mol Cell Cardiol 2007;43(6):677-85.

35. Wat MJ, Shchelochkov OA, Holder AM, Breman AM, Dagli A, Bacino C, Scaglia F, Zori RT, Cheung SW, Scott DA, Kang S-HL. Chromosome 8p23.1 deletions as a cause of complex congenital heart defects and diaphragmatic hernia. Am J Med Genet A 2009;149A(8):1661-77.

36. Jay PY, Bielinska M, Erlich JM, Mannisto S, Pu WT, Heikinheimo M, Wilson DB. Impared mesenchymal cell function in Gata4 mutant mice Leeds to diaphragmatic hernias and primary lung defects. Dev Biol 2007;301(2):602-14.

37. Guimiot F, Dupont C, Fuentes-Duarte A, Aboura A, Bazin A, Khung Savatovsky S, Tillous-Borde I, Delezoide A-L, Azancot A. Maternal transmission of interstitial 8p23.1 deletion detected during prenatal diagnosis. Am J Med Genet A 2013;161A(1):208-13.

38. López I, Bafalliu JA, Bernabé MC, García F, Costa M, Guillén-Navarro E. Prenatal diagnosis of de novo deletions of 8 p23.1 or $15 q 26.1$ in two fetuses with diaphragmatic hernia and congenital heart defects. Prenat Diagn 2006;26(6):577-80.

39. Hoellen F,Weichert J. Sonographic diagnosis of multiple cardiovascular malformations in a fetus with an interstitial 8p23.1 deletion. J Ult Med 2012;31(10):1689-92.

40. Kleefstra T, Smidt M, Banning MJG, Oudakker AR, Van Esch $H$, de Brouwer AP, Nillesen W, Sistermans EA, Hamel BC, de Bruijn D, Fryns JP, Yntema HG, Brunner HG, de Vries BBA, van Bokhoven $\mathrm{H}$. Disruption of the gene euchromatin histone methyl transferase1 (Eu-HMTase1) is associated with the 9q34 subtelomeric deletion syndrome. J Med Genet 2005;42(4):299-306.

41. Kleefstra T, van Zelst-Stams WA, Nillesen WM, Cormier-Daire V, Houge G, Foulds N, van Dooren M, Willemsen MH, Pfundt R, Turner A, Wilson M, McGaughran J, Rauch A, Zenker M, Adam MP, Innes M, Davies C, López AG, Casalone R, Weber A, Brueton LA, Navarro AD, Bralo MP, Venselaar H, Stegmann SP, Yntema HG, van Bokhoven H, Brunner HG. Further clinical and molecular delineation of the $9 q$ subtelomeric deletion syndrome supports a major contribution of EHMT1 haploinsufficiency to the core phenotype. J Med Genet 2009;46(9):598606.

42. Bock I, Németh K, Pentelényi K, Balicza P, Balázs A, Molnár MJ, Román V, Nagy J, Lévay G, Kobolák J, Dinnyés A. Targeted next generation sequencing of a panel of autism-related genes identifies an EHMT1 mutation in a Kleefstra syndrome patient with autism and normal intellectual performance. Gene 2016;595(2):131-41.
43. Willemsen MH, Vulto-van Silfhout AT, Nillesen WM, WissinkLindhout WM, van Bokhoven H, Philip N, Berry-Kravis EM, Kini U, van Ravenswaaij-Arts CM, Delle Chiaie B, Innes AM, Houge G, Kosonen T, Cremer K, Fannemel M, Stray- Pedersen A, Reardon W, Ignatius J, Lachlan K, Mircher C, Helderman van den Enden PT, Mastebroek M, Cohn-Hokke PE, Yntema HG, Drunat S, Kleefstra T. Update on Kleefstra Syndrome. Mol Synd 2012;2(3-5):202-12.

44. Guterman $S$, Hervé $B$, Rivière J, Fauvert $D$, Clement $P$, Vialard F. First prenatal diagnosis of a'pure' 9q34.3 deletion (Kleefstra syndrome): A case report and literature review. J Obst Gyn Res 2018;44(3):570-75.

45. Chen CP, Lin CL, Chen LL, Lee CC, Wang W. Prenatal diagnosis of mosaic ring chromosome 9. Pren Diagn 2006;26(9):870-71.

46. Chen CP, Lin CJ, Chen YY, Wang LK, Chern SR, Wu PS, Su JW, Chen LF, Town DD, Pan CW, Wang W. 3q26.31-q29 duplication and 9q34.3 microdeletion associated with omphalocele, ventricular septal defect, abnormal first-trimester maternal serum screening and increased nuchal translucency: Prenatal diagnosis and aCGH characterization. Gene 2013;532(1):80-86.

47. Penacho V, Galán F, Martín-Bayón TA, Mayo S, Manchón I, Carrasco A, Martínez-Castellano F, Alcaraz LA. Prenatal diagnosis of a female fetus with ring chromosome $9,46, X X, r(9)(p 24 q 34)$, and a de novo interstitial 9p deletion. Cytog Gen Res 2014;144(4):275-79.

48. Simovich MJ, Yatsenko SA, Kang SHL et al. Prenatal diagnosis of a 9q34.3 microdeletion by array-CGH in a fetus with an apparently balanced translocation. Pren Diag 2007;27(12):1112-17.

49. Huang LY, Yang Y, He P, Li DZ. Increased first-trimester nuchal translucency associated with a dicentric chromosome and 9q34.3 microdeletion syndrome. J Obst Gyn 2017;37(3):327-29.

50. Noruzinia M, Ahmadvand M, Bashti O, Salehi Chaleshtori AR. Kleefstra syndrome: the first case report from Iran. Acta Med Iran 2017;55(10):650-54.

51. Chen CP, Lin SP, Li HB, Chen YN, Wang W. Pregnancy with de novo 9q34.3 microdeletion and Kleefstra syndrome in the fetus may be associated with an abnormal maternal serum screening result. $T \mathrm{~J}$ Obst Gyn 2015;54(4):450-1.

52. Campbell CL, Collins RTII, Zarate YA. Severe neonatal presentation of Kleefstra syndrome in a patient with hypoplastic left heart syndrome and 9q34.3 microdeletion. Birt Def Res A Clin Mol Teratol 2014;100(12):985-90.

53. Hadzsiev K, Komlosi K, Czako M, Duga B, Szalai R, Szabo A, Postyeni E, Szabo T, Kosztolanyi G, Melegh B. Kleefstra syndrome in Hungarian patients: additional symptoms besides the classic phenotype. Mol Cytogenet 2016;9:22.

54. Ciaccio C, Scuvera G, Tucci A, Gentilin B, Baccarin M, Marchisio P, Avignone S, Milani D. New Insights into Kleefstra Syndrome: Report of two novel cases with previously unreported features and literature review. Cytog Gen Res 2018;156(3):127-33.

55. Van den Veyver IB, Patel A, Shaw CA, Pursley AN, Kang SH, Simovich MJ, Ward PA, Darilek S, Johnson A, Neill SE, Bi W, White LD, Eng CM, Lupski JR, Cheung SW, Beaudet AL. Clinical use of array comparative genomic hybridization (aCGH) for prenatal diagnosis in 300 cases. Pren Diag 2009;29(1):29-39.

56. Blue GM, Kirk EP, Giannoulatou E, Sholler GF, Dunwoodie SL, Harvey RP, Winlaw DS. Advances in the genetics of congenital heart disease: a clinician's guide. J Am Coll Cardiol 2017;69(7):859-70.

57. Valsesia A, Macé A, Jacquemont S, Beckmann J, Kutalik Z. The growing importance of CNVs: new insights for detection and clinical interpretation. Front Genet 2013;4:92. 